\title{
Water Productivity of Poplar and Paulownia on Two Sites in Kyrgyzstan, Central Asia
}

\author{
Niels Thevs ${ }^{1,2^{*}}$, Clara Baier ${ }^{3}$, Kumar Aliev ${ }^{1}$ \\ ${ }^{1}$ World Agroforestry, Central Asia Office, Bishkek, Kyrgyzstan \\ ${ }^{2}$ Gesellschaft für Internationale Zusammenarbeit (GIZ), Bonn, Germany \\ ${ }^{3}$ Sachsen-Leinen e.V., Markkleeberg, Germany \\ Email: ^N.Thevs@cgiar.org, ^niels.thevs@giz.de
}

How to cite this paper: Thevs, N., Baier, C. and Aliev, K. (2021) Water Productivity of Poplar and Paulownia on Two Sites in Kyrgyzstan, Central Asia. Journal of Water Resource and Protection, 13, 293-308. https://doi.org/10.4236/jwarp.2021.134018

Received: February 27, 2021

Accepted: April 4, 2021

Published: April 7, 2021

Copyright $\odot 2021$ by author(s) and Scientific Research Publishing Inc. This work is licensed under the Creative Commons Attribution International License (CC BY 4.0).

http://creativecommons.org/licenses/by/4.0/

\section{(c) (i) Open Access}

\begin{abstract}
As Central Asia is a region with wide spread water scarcity as a result of excessive irrigation of agriculture, land use changes deserve research about potential impacts on the already strained water resources. Poplars have a long tradition as agroforestry tree across Central Asia, while paulownia is new to the region, but has been gaining extreme attention as a potential plantation and/or agroforestry tree. Therefore, the water productivity of those two tree species is investigated here on 3-year-old trees, in order to provide insights in how far the newly introduced Paulownia could put additional strain on water resources compared to paulownia. Poplar $(P$. deltoides $\times$ nigra) increased the stem biomass by $5.4 \mathrm{~kg}$ at an average water consumption of $4.18 \mathrm{l} / \mathrm{d}$ (water productivity $6.79 \mathrm{~g} / \mathrm{l}$ ). Paulownia's (Paulownia tomentosa $\times$ fortunei) stem biomass grew by $4.81 \mathrm{~kg}$ at $2.36 \mathrm{l} / \mathrm{d}$ in average (water productivity $11.9 \mathrm{~g} / \mathrm{l}$ ). Expanding paulownia would not exert more pressure on Central Asia's water resources than an expansion of poplar.
\end{abstract}

\section{Keywords}

Fast-Growing Trees, Water Consumption, Sap Flow, Central Asia, Semi-Arid Climate

\section{Introduction}

Central Asia is largely covered by drylands, ranging from steppes in Northern and Central Kazakhstan to deserts further south in Southern Kazakhstan, Uzbekistan, and Turkmenistan, and mountain areas, mainly concentrated in Kyrgyzstan and Tajikistan, which also are exposed to a semi-arid climate in large parts [1]. 
Due to the arid climate across large parts of that region, agriculture, including agroforestry and tree plantations, depends on irrigation and therefore is concentrated along the rivers of the region. Excessive water withdrawal from rivers for irrigation has resulted in water scarcity, in particular along downstream river stretches, and large-scale land degradation with the desiccation of the Aral Sea being the most extreme example. Climate change is expected to aggravate strains on water resources latest in the second half of this century [2]. Tree wind breaks are one option to reduce water consumption in agriculture and build resilience against heat waves due to climate change, while providing additional resources and income opportunities to farmers [3] [4] [5].

Due to the arid to semi-arid climate, the countries in Central Asia are forest poor countries [6] [7] [8] [9] [10]. Furthermore, after the Soviet Union had disintegrated and the countries in Central Asia had gained independence, the energy supplies in particular to Kyrgyzstan and Tajikistan and to rural areas of Kazakhstan, Uzbekistan, and Turkmenistan ceased so that people in those areas had to switch to wood as primary energy source, which resulted in large scale forest and woodland degradation. Today, this forest degradation has slowed down, but forests and woodlands are still under pressure [7]. Due to that low forest cover, the countries across Central Asia have to import most of the wood demanded on their domestic markets [10]. Against this background, the policy programs of Kyrgyzstan and its neighboring countries seek to promote fast-growing trees in plantations and in agroforestry, examples being the Green Economy Program in Kyrgyzstan, the recent Strategy to Develop the Agriculture in the Republic of Uzbekistan 2020-2030, or the Kazakhstan-2050 strategy as reviewed by [7].

Poplar has a long-standing tradition as an agroforestry tree across Central Asia, particularly in the form of tree lines serving as wind breaks [3] [4], but is increasingly planted in plantations and wood lots as well [7]. Paulownia is an up-and-coming fast-growing tree species that has increasingly been attracting the attention of land users and policy makers across Central Asia as a source of readily marketable wood produced in untypically short time spans. Over the past five years, Paulownia spec. has been introduced to Kyrgyzstan in several pilot plantations across the country [11]. In China, its country of origin, the genus has widely and successfully been used for intercropping (both timber-oriented or focused on an improved microclimate for crops) with e.g. wheat, maize, millet, and vegetables [12] [13] [14] [15] since the 1980s, suggesting its suitability for integration into Central Asian agroforestry systems as well.

Against the background of limited and expectedly further strained water resources, it is crucial that new tree species introduced into the region's agricultural landscape, such as Paulownia spec., be assessed as to whether or to what extent they bear the risk of bringing a new large water consumer to an already water-stressed area. This study, therefore, addressed this question by investigating the water consumption and water productivity of poplar and paulownia on two different sites in Kyrgyzstan. 


\section{Methods}

\subsection{Study Sites}

The poplar trees investigated in this study were located in an experimental plot that had been established in 2018 near Bishkek, Kyrgyzstan, to test the growth performance of 11 poplar cultivars new to Central Asia [16]. The climate is classified as hot continental (Table 1). The soil is a silty loam with humus present in the topsoil that has been formed by the previous herbaceous vegetation.

This plot has an area of $15 \mathrm{~m} \times 20 \mathrm{~m}$. In spring 2018 (7 Apr 2018), after clearing the plot from vegetation, cuttings of $20 \mathrm{~cm}$ length were planted with a distance of $1.0 \mathrm{~m}$ between rows and $0.6 \mathrm{~m}$ within rows. The poplars planted here were $P$. deltoides $\times$ nigra, $P$. nigra $\times$ maximoviczii, $P$. maximoviczii $\times$ trichocar pa hybrids, and one $P$. trichocarpa cultivar. The plot was equipped with a drip irrigation system through which the cuttings were irrigated 2 - 3 times per week during their first and second year (2018 and 2019) and once per week during their third year (2020). Weeds were cleared manually every three weeks from the planting date until August 2018, when the trees had grown large enough to outcompete the weeds.

In spring 2020, all trees were cut back to their stumps, except for three trees of each cultivar at the distant end of each dripline. This resulted in an unchanged distance of $1.0 \mathrm{~m}$ between rows, whereas the distance between the remaining trees within a row increased to $1.20 \mathrm{~m}$. The three sample trees for this sap flow study were the three remaining trees of the cultivar $\mathrm{H}-17 . \mathrm{H}-17$ is a $P$. deltoides $\times$ nigra hybrid purchased from Biopoplar, Italy.

The paulownia trees examined in this study belong to a plantation that is located on the northern shore of Lake Issyk-Kul just west of the village Orn'ok (Table 1). The climate at that plantation is cold semi-arid according to the Köpper-Geiger climate classification. The soil is very dense and compacted with a silty to loamy texture, and stones which account for $20 \%$ of the total soil volume. There is no humus present, as there was no significant vegetation before that land had given way to this paulownia plantation (Baier et al., submitted).

Table 1. Geographical position, elevation, and climate features of the two study sites Bishkek and Orn'ok.

\begin{tabular}{ccc}
\hline Site & Poplar site - Bishkek & Paulownia site - Orn'ok \\
\hline Geographical position & $42.92^{\circ} \mathrm{N} 74.62^{\circ} \mathrm{E}$ & $42.60^{\circ} \mathrm{N}, 76.83^{\circ} \mathrm{E}$ \\
Elevation [m above sea level] & 701 & 1636 \\
Climate features & & \\
Average January Temperature $\left[{ }^{\circ} \mathrm{C}\right]$ & -2.6 & -11.2 \\
Average July Temperature $\left[{ }^{\circ} \mathrm{C}\right]$ & 24.9 & 18.7 \\
Annual precipitation $[\mathrm{mm}]$ & 452 & 297
\end{tabular}

Sources: Climate Bishkek: http://www.weatherbase.com/. Climate Ornok (i.e. climate data from Cholpon Ata, which is $20 \mathrm{~km}$ from Ornok, also located on the shore of Issyk Kul):

https://de.climate-data.org/asien/kirgisistan/issyk-kul/cholpon-ata-30066/. 
The plantation comprises 5500 trees, which all belong to the hybrid Paulownia tomentosa $\times$ fortunei (brand name Shan Tong). The trees were planted in May 2017 with a distance of $4 \mathrm{~m}$ between rows and $3 \mathrm{~m}$ between trees within the same row and cut back to the trunk in April 2018 to induce the development of a stronger root system relative to the above ground biomass. In this plantation, three average-sized trees were chosen from the center part of the plantation for the measurements of sap flow of all three tree rings, stem volume, and stem biomass development over the course of the 2020 growing season. These trees are labelled W1-3. Adjacent and east of those three trees, three further average sized trees were chosen to measure the sap flow of the outer tree ring, the 2020 tree ring. Those trees are hereinafter referred to as E1-3. The trees were irrigated via drip irrigation, starting mid-May. From June onwards, the plantation was irrigated twice per week until mid-September, whereby the entire plantation area received a total of $30 \mathrm{~m}^{3}$ water per round of irrigation.

\subsection{Measuring Stem Volume and Biomass Production}

The stem volumes of the sample trees were assessed through diameter measurements at $0.05 \mathrm{~m}$ above ground (base level), sap flow sensor level (which varied between 0.5 and $1.0 \mathrm{~m}$ depending on tree shape), $1.0 \mathrm{~m}, 1.30 \mathrm{~m}(\mathrm{DBH}=$ diameter at breast height), and $2.00 \mathrm{~m}$, complemented by total stem height. The volumes were converted into biomass by multiplication with the wood's basic density, which amounts to $0.35 \mathrm{~g} / \mathrm{cm}^{3}$ for poplar (http://www.fao.org/3/j2132s/J2132S16.htm) and $0.28 \mathrm{~g} / \mathrm{cm}^{3}$ for paulownia (Baier et al., submitted). On the paulownia plantation, next to the sample trees W1-3 and E1.3 six additional trees were measured, in order to ensure that the samples trees were average sized.

Diameter(s), stem height, stem volume, and biomass of each sample tree were determined at the beginning and the end of the growing season 2020. The annual increment in stem volume and biomass-the difference between the readings early and late in the season-finally allows for the calculation of water productivity.

\subsection{Quantifying Sap Flow}

Sap flow refers to the water movement inside a tree stem and was determined employing the thermal dissipation method after [17] on both sites with a temporal resolution of ten minutes. On 13 May 2020 (DOY 134), the three poplar (H-17) sampling trees were equipped with $20 \mathrm{~mm}$ sap flow sensor needles, all connected to the same data logger. The entire sap flow system had been purchased from UP GmbH, Germany. Said sap flow unit was checked every 14 days until it was disassembled on 17 Sep 2020. Earlier, on 4 Apr 2020 (DOY 95), a sensor and logger (EM 50 from Decagon Devices, U.S.) had been placed at the poplar site to record air temperature and air humidity until 10 Oct 2020 (DOY 284). Leaves began to emerge on 4 Apr 2020, were fully developed by $21 \mathrm{Apr}$ 2020 (DOY 112), and had entirely changed color in autumn by 10 Oct 2020 
(DOY 284). Thus, the growing season was defined as the period of time from 4 Apr to 10 Oct 2020.

As for paulownia, the first sap flow sensor pairs were inserted on 26 May 2020 (DOY 147) into the 2019 tree rings of the trees W1, 2, and 3, remaining in place until 19 Oct 2020 (DOY 292). On 23 Jun 2020 (DOY 175), three sensor pairs were inserted into these trees' (W1, 2, and 3) 2018 tree rings until removal on 23 Jul 2020 (DOY 205). By 7 Jul 2020 (DOY 189), the 2020 tree ring had reached a thickness of $11 \mathrm{~mm}$, allowing for three additional sensor pairs to be inserted into the 2020 tree ring of trees W1, 2, and 3, which remained there until 19 Oct 2020. Finally, on 23 Jul 2020 (DOY 205), the 2020 tree ring of the trees E1, 2, and 3 was equipped with three sensor pairs each which also remained in place until 19 Oct 2020 (DOY 284). All sensor needles installed into paulownia were $10 \mathrm{~mm}$ long. The sensor pairs which addressed the different tree rings were installed at least $20 \mathrm{~cm}$ away from other sensor pairs and in a direction that faced at least $45^{\circ}$ away from other sensor pairs. A climate sensor for air temperature and air humidity and logger (EM 50 from Decagon Devices, U.S.) were placed at the paulownia site to record air temperature and air humidity from 1 May to 19 Oct 2020. Leaves began to emerge shortly after 1 May 2020, were fully developed by 9 Jun, and turned dry in October. During the second half of October, plantation staff shook the leaves from the trees for utilization as animal fodder. The growing season at this site was defined as 1 May to 19 Oct 2020.

The raw data recorded by the sap flow loggers, the temperature difference between the two needles of one given pair $(\Delta T)$, was processed using Baseliner, a software developed specifically for this purpose by [18]. This software is used to identify the zero-flow reference $\Delta T_{\max }$ at night, which is needed to calculate the sap flow velocity $u$. Firstly, the flow index $k$ is calculated:

$$
k=\frac{\Delta T_{\max }-\Delta T}{\Delta T}
$$

The $k$ values are used to calculate the sap flow velocity $u$ in $\mathrm{ml} / \mathrm{cm}^{2} \mathrm{~min}$ according to the directions provided by [19] and [20]:

$$
u=0.714 k^{1.231}
$$

Determining $\Delta T_{\max }$ requires the water vapor pressure deficit (VPD), as it is assumed that at very low VPD, transpiration and, therefore, sap flow come to a complete halt.

VPD was calculated based on the temperature and air humidity data recorded at the two sites:

$$
\mathrm{VPD}=e_{s}-e_{a}
$$

As detailed in [21], saturated vapor pressure $e_{s}[\mathrm{kPa}]$ is related to the air temperature and calculated as follows:

$$
e_{s}(T)=0.6108 \exp \left(\frac{17.27 \cdot T}{T+237.3}\right)
$$

The actual vapor pressure $e_{a}[\mathrm{kPa}]$ takes into account the relative humidity $\mathrm{RH}$ 
[\%] recorded on site:

$$
e_{a}(T)=e_{s} \cdot \mathrm{RH}
$$

The 10-minute values of the sap flow velocities were aggregated to daily sap flow velocities (expressed in $\mathrm{ml} / \mathrm{cm}^{3} \mathrm{~d}$ ). These daily sap flow velocities were plotted against daily mean VPD values to establish relationships that allowed to fill data gaps in the sap flow measurements, in particular for the 2018 and 2020 tree rings of paulownia, which had been monitored by sap flow sensors for only short time spans. [22] reports that in Populus alba, VPD exhibited the closest relationship to sap flow compared to other climate features such as temperature, humidity, radiation, or wind speed. The data stems from on a location in Kazakhstan situated between the two sites of this study.

Following this, daily sap flow, $F_{s}$ (in $\mathrm{ml} / \mathrm{d}$ ) was calculated:

$$
F_{s}=u \cdot A
$$

$A$ is the hydro-active sapwood area $A\left[\mathrm{~cm}^{2}\right]$.

For the poplar trees, the entire stem cross-sectional area except for the bark was considered hydro-active sapwood area. The stem diameter at sensor height was measured at the beginning of the season, at least once per month during the growing season, and at the end of the season, when the sap flow sensors were removed. Plotted against time, these measurements yielded models for the increase of the hydro-active area over the course of the growing season.

The tree rings of paulownia were addressed as independent cross-sectional areas, as tree rings of different age differ in their water conductance behavior [11]. The stem diameters and areas corresponding to the 2018 and 2019 tree ring were assessed using tree cores from the end of the growing season 2020. During the growing season 2020, the stem diameter was measured every two weeks, which allowed to model the increment of the cross-sectional area of the 2020 tree ring in the course of the growing season 2020.

\subsection{Quantifying Water Productivity}

Water productivity refers to the agricultural (sometimes also economic) output per unit of water consumed and can be applied to both rainfed and irrigated agriculture [23]. In this study, the water consumed was measured through sap flow, which is upward water movement in the stem. That water movement is driven by the transpiration through the leaves, which is the water consumed by a tree. This study focuses on stem biomass production, as that is the part of the trees most relevant for wood harvest. In order to determine individual water productivity, the increment in trunk biomass per tree over the entire growing season 2019 was divided by total tree water consumption during said period.

\section{Results}

\subsection{Stem Volumes and Biomass Increment}

The poplar trees started with a much smaller stem volume and stem biomass 
(Table 2) than the three paulownia trees. At the beginning of the season, the paulownia trees were twice as large in DBH than the poplars, while the poplars were taller. Over the course of the season, the poplar trees roughly tripled their stem biomass, while the paulownia trees only increased their stem biomass by $60 \%$, as shown in Table 3. The average stem volume of the three paulownia sample trees W1-3 (42.9 $\pm 0.4 \mathrm{l})$ did not differ significantly from the average stem volume of the neighboring trees $(37.4 \pm 91)$, according to a t-test.

\subsection{Sap Flow Data and Tree Water Consumption}

The sap flow velocity per day (the amount of water that moves upward through the stem per $\mathrm{cm}^{2}$ stem area per day) of the three poplar sample trees coincided with VPD as shown in Figure 1. For example, on DOY 162 and 179 VPD dropped sharply, which corresponded to sharp drops of the sap flow velocities of

Table 2. DBH, tree height, stem volume and stem biomass of the poplar sample trees at the beginning and end of the growing season 2020 .

\begin{tabular}{cccc}
\hline Tree feature & Tree 1 & Tree 2 & Tree 3 \\
\hline Beginning of season 2020 & & & \\
DBH [cm] & 4.1 & 4.1 & 4 \\
Height [m] & 6.4 & 6 & 6 \\
Volume [1] & 5.4 & 5.3 & 4.6 \\
Biomass [kg] & 1.9 & 1.86 & 1.62 \\
End of season 2020 & & & 6.8 \\
DBH [cm] & 8.1 & 6.8 & 8.3 \\
Height [m] & 9.9 & 8.4 & 16.3 \\
Volume [1] & 27.8 & 17.6 & 5.7 \\
Biomass [kg] & 9.72 & 6.15 & \\
\hline
\end{tabular}

Table 3. DBH, tree height, stem volume and stem biomass of the paulownia sample trees W 1-3 from 2020 at the beginning and end of the growing season 2020 .

\begin{tabular}{cccc}
\hline Tree feature & W 1 & W 2 & W 3 \\
\hline Beginning of season 2020 & 8 & 8.1 & 8.3 \\
DBH [cm] & 3 & 2.7 & 2.9 \\
Height [m] & 25 & 24.9 & 27.2 \\
Volume [1] & 7 & 6.98 & 7.82 \\
Biomass [kg] & 10.8 & & 10.8 \\
End of season 2020 & 5.6 & 11 & 5.5 \\
DBH [cm] & 42.9 & 5.6 & 42.5 \\
Height [m] & 12 & 43.4 & 11.9 \\
Volume [1] & 12.12 & \\
Biomass [kg] & & & \\
\hline
\end{tabular}



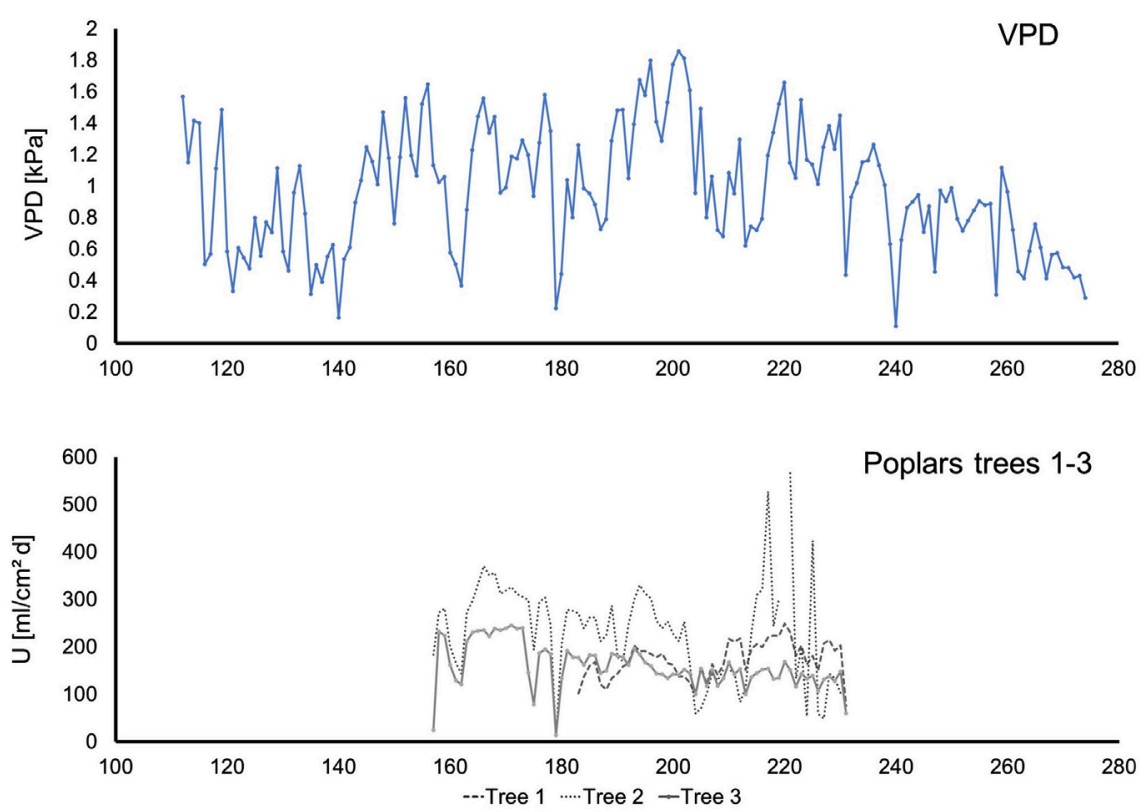

Figure 1. VPD and sap flow velocities $\left(\mathrm{u}\left[\mathrm{ml} / \mathrm{cm}^{2} \cdot \mathrm{d}\right]\right)$ of the three poplar trees. The $\mathrm{x}$-axis displays the nth day of the year 2020 from the 100th day (9 Apr 2020) to 300th day (26 Oct 2020) of the year 2020.

trees 2 and 3. After a longer high from DOY 192, VPD dropped again on DOY 204 and remained low until DOY 208, which also was reflected by a drop in sap flow velocities of all three trees on DOY 204 with sap flow velocities remaining low for a couple of days afterwards. The peak of VPD on DOY 166 coincided with a peak sap flow velocity of tree 2 at the same day.

The data gaps in the daily sap flow velocities were filled based on the formulae in Table 4. Thereby, the factor to calculate sap flow velocity was substantially higher for tree 2 compared to the two other trees.

All three paulownia trees for which there is sap flow data on the three 2018-2020 tree rings exhibited a similar pattern with regard to sap flow velocity (Figure 2): Sap flow densities were highest in the 2020 tree ring, followed by those in the 2019 tree ring for the majority of days. The sap flow densities in the 2018 tree ring consistently ranged substantially lower than those the 2019 tree ring. The 2020 tree rings of the $\mathrm{E}$ trees recorded slightly higher sap flow densities than the 2020 tree ring of the trees in row $\mathrm{W}$, but in the same range. The sap flow densities of the tree ring from 2019 were rather low until DOY 185 and increased substantially around DOY 190, whereby increase was more pronounced for tree W1 and W2 as compared to tree W3. Towards the end of the growing season, the sap flow densities in the tree rings of 2019 and 2020 decreased along with the cooler weather during autumn and the trees gradually shedding their leaves.

During summer, changes in daily mean VPD translated into changes of daily sap flow velocities (Figure 2) as was previously shown for the poplar trees. For example, VPD dropped on DOY 214, which was reflected in the sap flow velocities 



Figure 2. VPD and sap flow velocities $\left(\mathrm{u}\left[\mathrm{ml} / \mathrm{cm}^{2} \cdot \mathrm{d}\right]\right)$ of the tree rings of 2018,2019 , and 2020 of the three paulownia trees in row $\mathrm{W}$ and sap flow velocity of the tree rings 2020 of the three specimen in row $\mathrm{E}$. The $\mathrm{x}$-axis displays the nth day of the year 2020 from the 140th day (19 May 2020) to the 300th day (26 Oct 2020) of the year 2020.

Table 4. Formulae that served to fill in missing daily sap flow velocities ( $u$ in $\mathrm{ml} / \mathrm{cm}^{2} \mathrm{~d}$ ) for the three poplar sampling trees based on VPD (in $\mathrm{kPa}$ ) with their respective coefficients of determination $\mathrm{R}^{2}$ (square of the Bravais-Pearson Correlation Coefficient).

\begin{tabular}{ccc}
\hline Tree no. & Formulae to fill missing sapflow velosities & $\mathrm{R}^{2}$ \\
\hline 1 & $\mathrm{u}=133.64 * \mathrm{VPD}$ & 0.91 \\
2 & $\mathrm{u}=191.97 * \mathrm{VPD}$ & 0.82 \\
3 & $\mathrm{u}=130.05 * \mathrm{VPD}$ & 0.89 \\
\hline
\end{tabular}


of the 2019 and 2020 tree ring of tree W1, W2 (albeit less pronounced), and W3. A similar response of the sap flow velocities to a dropping VPD was observed on DOY 231 (Figure 2). The sap flow velocities of the 2020 tree rings of the trees from the eastern row (trees E1-3) also dropped sharply on DOY 214 and 231 (Figure 2).

The factors, which were found to calculate sap flow velocity (Table 5), were highest for the 2020 tree rings, followed by the 2019 and 2018 tree rings. This underlined that the outer tree ring contributed most actively to total sap flow, while the inner tree ring (from 2018) nearly became inactive with regard to water transport.

\subsection{Water Productivity}

Looking at the average values of volume and biomass increase, water consumption, and resulting water productivity, the poplar trees attained more volume and biomass growth during the growing season 2020 (Table 3 and Table 6), but consumed substantially more water (795 l per tree and growing season) than the paulownia trees with 404.11 per tree and growing season (Table 7). As a result, the water productivity of the poplar trees was $6.79 \mathrm{~g}$ biomass per liter of water consumed, whereas paulownia produced $11.9 \mathrm{~g}$ biomass per liter of water consumed.

Table 5. Formulae that served to fill in missing daily sap flow velocities ( $\mathrm{u}$ in $\mathrm{ml} / \mathrm{cm}^{2} \mathrm{~d}$ ) for the three paulownia sampling trees W 1-3 and the three tree rings based on VPD (in $\mathrm{kPa}$ ) with their respective coefficients of determination $\mathrm{R}^{2}$ (square of the Bravais-Pearson Correlation Coefficient).

\begin{tabular}{cccc}
\hline Tree no. & Tree ring & Formulae to fill missing sapflow velosities & $\mathrm{R}^{2}$ \\
\hline W 1 & 2018 & $\mathrm{u}=7.5283 * \mathrm{VPD}$ & 0.42 \\
W 1 & 2019 & $\mathrm{u}=50.577 * \mathrm{VPD}$ & 0.64 \\
W 1 & 2020 & $\mathrm{u}=110.84 * \mathrm{VPD}$ & 0.85 \\
W 2 & 2018 & $\mathrm{u}=4.1501 * \mathrm{VPD}$ & 0.35 \\
W 2 & 2019 & $\mathrm{u}=47.415 * \mathrm{VPD}$ & 0.72 \\
W 2 & 2020 & $\mathrm{u}=85.951 * \mathrm{VPD}$ & 0.74 \\
W 3 & 2018 & $\mathrm{u}=3.6359 * \mathrm{VPD}$ & 0.62 \\
W 3 & 2019 & $\mathrm{u}=19.314 * \mathrm{VPD}$ & 0.55 \\
W 3 & 2020 & $\mathrm{u}=93.191 * \mathrm{VPD}$ & 0.82 \\
\hline
\end{tabular}

Table 6. Volume and biomass increments, water consumption, and water productivity of the Poplar sample trees during the season 2020. SD refers to standard deviation.

\begin{tabular}{ccccc}
\hline Feature & Tree 1 & Tree 2 & Tree 3 & Average \pm SD \\
\hline Volume increment [l] & 22.3 & 12.3 & 11.7 & $15.4 \pm 6$ \\
Biomass increment [kg] & 7.82 & 4.3 & 4.08 & $5.4 \pm 2.1$ \\
Water consumption per tree, average per day [1] & 4.13 & 5.03 & 3.39 & $4.18 \pm 0.82$ \\
Water consumption per tree [1], whole season & 785.4 & 956 & 643.5 & $795 \pm 156$ \\
Water productivity [g/l] & 9.96 & 4.49 & 6.34 & $6.79 \pm 2.78$ \\
\hline
\end{tabular}


Table 7. Volume and biomass increments, water consumption, and water productivity of the paulownia sample trees during the season 2020. SD refers to standard deviation.

\begin{tabular}{ccccc}
\hline Feature & W 1 & W 2 & W 3 & Average \pm SD \\
\hline Volume increment [1] & 17.8 & 18.4 & 15.3 & $17.2 \pm 1.6$ \\
Biomass increment [kg] & 5 & 5.16 & 4.29 & $4.81 \pm 0.46$ \\
Water consumption per tree, average per day [1] & 3.26 & 2.35 & 1.48 & $2.36 \pm 0.89$ \\
Water consumption per tree [1], whole season & 557 & 402,6 & 252,7 & $404.1 \pm 152$ \\
Water productivity [g/l] & 8.97 & 12.81 & 16.97 & $11.9 \pm 4$ \\
\hline
\end{tabular}

\section{Discussion}

The biomass yield of the three poplar sample trees amounted to $19.7 \mathrm{t} / \mathrm{ha}^{*} \mathrm{a}$ (calculated from 2018, the year of planting, until 2020 [16]), which is in the range of an NPP of 12 to $24 \mathrm{t} / \mathrm{ha}^{*} \mathrm{a}$ for $P . \times$ canadensis as listed by [24], but higher than the biomass yields of 12.9 to $13.6 \mathrm{t} / \mathrm{ha}^{*} \mathrm{a}$ as reported by [25] from Idaho and California.

The average daily water consumption over the three poplar trees was $4.18 \mathrm{l} / \mathrm{d}$ (Table 6), which is equivalent to approximately $4-5 \mathrm{~mm} / \mathrm{d}$, considering a crown area of about $0.8-1.0 \mathrm{~m}^{2}$. This assumption is based on the tree-to-tree distances of $1.0 \mathrm{~m}$ between rows and $1.2 \mathrm{~m}$ within rows, respectively. The values are in the range of daily water consumptions of $4 \mathrm{~mm} / \mathrm{d}$ and $3.9 \mathrm{~mm} / \mathrm{d}$ as published by [26] and [27], respectively, both for $P$. gansuensis in Northwest China. [22] reported daily average water consumptions of $P$. alba in the Chui Valley in Kazakhstan of $2.6-4.8 \mathrm{~mm} / \mathrm{d}$. Furthermore, [28] reported similar daily water consumptions of $3.6 \mathrm{~mm} / \mathrm{d}$ in average with a maximum of $4.8 \mathrm{~mm} / \mathrm{d}$ for P. trichocarpa $\times$ deltoides from Washington State, U.S. As the three poplar trees sampled in this study were not surrounded by equally tall trees, their water consumption might be higher compared to a situation in a contiguous plantation, because the trees are exposed to higher wind speed due to the absence of neighboring trees.

On average, 10-year-old paulownia trees reach a DBH of 35 to $40 \mathrm{~cm}$ and a volume of 0.3 to $0.5 \mathrm{~m}^{3}$ [12] [29], which would be equivalent to an average annual DBH increment of 3.5 to $4 \mathrm{~cm}$ and an average annual volume increment of 30 to 50 1. [30] studied growth rates of paulownia trees in Bishkek, Kyrgyzstan, and measured an annual DBH and volume increment of 4.9 to $6.6 \mathrm{~cm}$ and 30 to $40 \mathrm{l}$, respectively. All those readings are well above the DBH and volume increment observed in this study on paulownia trees. This can be explained by a shorter growing season and cooler summer temperatures compared to e. g. Bishkek. The lack of a significant difference between the stem volume of the sample trees W1-3 and the neighboring trees indicates that the paulownia sample trees were representative for the central part of the plantation.

Previous studies calibrated sap flow measurement methods based on sensors planted into trees against gravimetrical or volumetrical measurements of sap flow and found that the thermal dissipation method, as used here, systematically underestimated tree sap flow. [31] published an underestimation by the factor 
2.5 for Fagus grandifolia, whereas [32] found an underestimation by only $23.3 \%$ when using long sensor needles and $45 \%$ when using short sensor needles across different tree species. In contrast, [33] reported that there was no deviation between sap flow measured through thermal dissipation versus gravimetrical sap flow measurement for diffuse porous tree species-like poplar, but found deviations for ring-porous tree species. A literature review [34] that compiled sap flow calibration studies revealed that thermal dissipation sap flow measurements, as used here, underestimated sap flow by $40 \%$. In conclusion, these publications suggest that the tree water consumptions of this study may be underestimations of the real tree water consumption. It appears, however, that this assumption more likely applies to paulownia than to poplar, or that the degree of underestimation is larger for paulownia than for poplar. The reasons: Firstly, sap flow in paulownia trees and tree rings was measured with short needles $(10 \mathrm{~mm})$, whereas longer needles of $20 \mathrm{~mm}$ were used for poplar. In addition, the study by [33] found no underestimation in diffuse-porous trees like poplars. In essence, the water productivities presented here should be considered optimistic numbers, more so for paulownia than for poplar.

[35] measured water use efficiencies on short rotation plantations of $P$. generosa $\times$ nigra under standard and double amount drip irrigation in Central Italy using the $\delta^{13} \mathrm{C}$ method to analyze the tree rings of the entire rotation period. The authors found water use efficiencies of $3.3 \mathrm{~g} / \mathrm{l}$ and $3.44 \mathrm{~g} / \mathrm{l}$ for the two irrigation treatments, respectively, which is significantly lower than the water productivity of $6.79 \mathrm{~g} / \mathrm{l}$ of this study. The water use efficiencies by [35] were calculated over a three-year rotation period, while this study only took into account the third year of tree growth after planting, which may partly account for this difference. In addition, the microclimate of the plantation of this study might be more humid considering the higher tree density in the experimental set-up of [35], which may help reduce water consumption. Finally, there may be an underestimation of water consumption by the sap flow method employed in this study, as discussed above.

The water consumption per paulownia tree over the growing season 2020, which came to an average of 404.1 l, has remained in the same range as the amount recorded over the preceding growing season 2019, which was 4521 per tree (Baier et al., submitted), while the stem biomass increment increased from an average of $2.77 \mathrm{~kg}$ per tree in 2019 [11] to $4.81 \mathrm{~kg}$ per tree in 2020. In consequence, the water productivity of these paulownia trees increased from $6.1 \mathrm{~g} / \mathrm{l}$ in 2019 [11] to $11.9 \mathrm{~g}$ as listed in Table 7. The paulownia tree water consumptions here are all derived from the trees of the western row because there, the sap flow velocities of all three tree rings had been measured. The sap flow velocities of the 2020 tree rings of the three trees in the eastern row exceeded those in the western row, as shown in Figure 2. This difference may indicate that the sap flow velocities of the 2020 tree rings in trees W1-3 and, therefore, their sap flow and water consumption (listed in Table 7), represent the lower boundary of sap flow in such outer tree rings. Following this argumentation, the tree water consump- 
tion and water productivity of paulownia as presented in Table 7 slightly underestimate factual tree sap flow and water productivity. [36] demonstrated that sap flow decreases with increasing tree age. Although the paulownia specimen studied in 2019 by [11] and in 2020 by this study are both still young trees, tree development may be a contributing factor to the lower water consumption per biomass increment unit.

\section{Conclusion}

This study investigated the water consumption, biomass increment, and resulting water productivity of young poplar $(P$. deltoides $\times$ nigra) and young paulownia (Paulownia tomentosa $\times$ fortunei) individuals, both planted in Kyrgyzstan under irrigation, being the first study to address water productivity of those agroforestry and plantation trees in the region Central Asia. The volume and biomass increment of the poplars investigated was in the range of other studies under similar climates, while the growth of paulownia was slower compared to other literature, which was explained by the colder climate and shorter growing season at the study site as compared to other investigations. The water consumption of poplar was in the range of other publications. The water consumption of paulownia during the growing season 2020 did not exceed that of the previous year (Baier et al., submitted) despite the trees' larger size. The water consumptions reported here (Table 7) may be underestimations, considering that a number of previous studies found the thermal dissipation method employed here to underestimate real sap flow. There are indications that this underestimation was more pronounced in paulownia than in poplar. Therefore, the water productivities for both species should be considered optimistic values, with the values for paulownia being slightly more optimistic than for poplar. In essence, paulownia has not been found to be more water-demanding than poplar, leading this paper to conclude that expanding paulownia as another fast-growing tree species would not exert more pressure on Central Asia's water resources than an expansion of poplar, a tree genus widely employed and appreciated in this dryland region.

\section{Acknowledgements}

Niels Thevs' position as an integrated expert at the World Agroforestry Center was funded by the German Federal Ministry of Economic Cooperation and Development (BMZ) as part of the Center for International Migration and Development (CIM) program. We thank the German Academic Exchange Service (DAAD), specifically the program RISE Worldwide, for issuing a scholarship that enabled Clara Baier to carry out research in Kyrgyzstan to lay the basis for the measurements on paulownia. The sap flow equipment and climate sensors had been funded through a previous project by the Fund for International Agricultural Research (FIA) under Deutsche Gesellschaft für Internationale Zusammenarbeit (GIZ), Germany. We furthermore express our gratitude to the land 
owner of the paulownia plantation for his support with this study.

\section{Conflicts of Interest}

The authors declare no conflicts of interest regarding the publication of this paper.

\section{References}

[1] CACILM and ADB (Central Asian Countries Initiative for Land Management and Asian Development Bank) (2010) Central Asia Atlas of Natural Resources. CACILM and ADB, Manila.

http://www.adb.org/sites/default/files/publication/27508/central-asia-atlas.pdf

[2] Reyer, C.P.O., Otto, I.M., Adams, S., Albrecht, T., Baarsch, F., Cartsburg, M., Eden, A., Ludi, E., Marcus, R. and Mengel, M. (2017) Climate Change Impacts in Central Asia and Their Implications for Development. Regional Environmental Change, 17, 1639-1650. https://doi.org/10.1007/s10113-015-0893-Z

[3] Thevs, N., Strenge, E., Aliev, K., Eraaliev, M., Lang, P. Baibagysov, A. and Xu, J. (2017) Tree Shelterbelts as an Element to Improve Water Resource Management in Central Asia. Water, 9, 842. https://doi.org/10.3390/w9110842

[4] Thevs, N., Gombert, A.J., Strenge, E., Lleshi, R., Aliev, K. and Emileva, B. (2019) Tree Wind Breaks in Central Asia and Their Effects on Agricultural Water Consumption. Land, 8, 167-183. https://doi.org/10.3390/land8110167

[5] Thevs, N., Aliev, K. and Lleshi, R. (submitted) Water Productivity of Tree Wind Break Agroforestry Systems in Irrigated Agriculture-An Example from Ferghana Valley, Kyrgyzstan. Trees, Forests, and People.

[6] Undeland, A. and Mitchell, A.M. (2015) Kyrgyz Republic-Communities, Forests, and Pastures.

https://documents.worldbank.org/en/publication/documents-reports/documentdet ail/550371468263989781/kyrgyz-republic-communities-forests-and-pastures

[7] UNECE (2019) Forest Landscape Restoration in the Caucasus and Central Asia-Challenges and Opportunities. Background Study for the Ministerial Roundtable on Forest Landscape Restoration in the Caucasus and Central Asia (21-22 June 2018, Astana, Kazakhstan).

http://www.unece.org/fileadmin/DAM/timber/Forest_Policy/Capacity_building/FL R_CCA_challenges_opportunities_081018-ENG-edited.pdf

[8] FAO (2020) Global Forest Resources Assessment. Country Reports 2020. http://www.fao.org/forest-resources-assessment/fra-2020/country-reports/en

[9] FRA (2020) Global Forest Resources Assessments. FAO, Rome. http://www.fao.org/forest-resources-assessment/fra-2020/country-reports/en

[10] FAOSTAT (2020). http://www.fao.org/faostat/en

[11] Baier, C., Thevs, N., Villwock, D., Emileva, B. and Fischer, S. (submitted) Water Productivity of Paulownia Tomentosa $\times$ Fortunei (Shan Tong) in a Plantation at Lake Issyk-Kul, Kyrgyzstan, Central Asia. Trees.

[12] Chinese Academy of Forestry (1986) Paulownia in China: Cultivation and Utilization. Asian Network for Biological Sciences and International Development Research Centre, Beijing.

[13] Jiang, Z., Gao, L., Fang, Y. and Sun, X. (1994) Analysis of Paulownia-Intercropping Types and Their Benefits in Woyang County of Anhui Province. Forest Ecology and Management, 67, 329-337. https://doi.org/10.1016/0378-1127(94)90027-2 
[14] Wang, Q. (1990) A Brief Account of Professional Education and Training in Agroforestry in China. Agroforestry Systems, 12, 87-89. https://doi.org/10.1007/BF00055577

[15] Wang, Q. and Shogren, J.F. (1992) Characteristics of the Crop-Paulownia System in China. Agriculture, Ecosystems \& Environment, 39, 145-152. https://doi.org/10.1016/0167-8809(92)90050-L

[16] Thevs, N., Fehrenz, S., Aliev, K., Emileva, B., Fazylbekov, R., Kentbaev, Y., Qonunov, Y., Qurbonbekova, Y., Raissova, N., Razhapbaev, M. and Zikirov, S. (submitted) Growth Rates of Poplar Clones across Central Asia. Forests.

[17] Granier, A. (1985) Une nouvelle méthode pour la mesure du flux de sève brute dans le tronc des arbres. Annales des Sciences forestières EDP Sciences, 42, 193-200. https://doi.org/10.1051/forest:19850204

[18] Oishi, A., Hawthorne, C., David, A. and Ram, O. (2016) Baseliner. An Open-Source, Interactive Tool for Processing Sap Flux Data from Thermal Dissipation Probes. SoftwareX, 5, 139-143. https://doi.org/10.1016/j.softx.2016.07.003

[19] Clearwater, M.J., Meinzer, F.C., Andrade, J.L., Goldstein, G. and Holbrook, N.M. (1999) Potential Errors in Measurement of Nonuniform Sap Flow Using Heat Dissipation Probes. Tree Physiology, 19, 681-687. https://doi.org/10.1093/treephys/19.10.681

[20] Smith, D.M. and Allen, S.J. (1996) Measurement of Sap Flow in Plant Stems. Journal of Experimental Botany, 47, 1833-1844. https://doi.org/10.1093/jxb/47.12.1833

[21] Zotarelli, L., Dukes, M.D., Romero, C.C., Migliaccio, K.W. and Morgan, K.T. (2010) Step by Step Calculation of the Penman-Monteith Evapotranspiration (FAO-56 Method). https://edis.ifas.ufl.edu/pdffiles/ae/ae45900.pdf

[22] Strenge, E., Thevs, N., Aliev, K., Eraaliev, M., Lang, P. and Baibagysov, A. (2018) Water Consumption of Populus alba Trees in Tree Shelterbelt Systems in Central Asia. Central Asian Journal for Water Resources, 4, 48-62. https://doi.org/10.29258/CAJWR/2018-RI.v4-1/48-62.eng https://cajwr.scholasticahq.com/article/5955.pdf

[23] Kassam, A.H., Molden, D., Fereres, E. and Doorenbos, J. (2007) Water Productivity: Science and Practice-Introduction. Irrigation Science, 25, 185-188.

https://doi.org/10.1007/s00271-007-0068-X

[24] Isebrands, J.G. and Richardson, J. (2014) Poplars and Willows. Trees for Society and the Environment. CAB International and FAO, Rome.

https://doi.org/10.1079/9781780641089.0000

[25] Stanton, B.J., Bourque, A., Coleman, M., Eisenbies, M., Emerson, R.M., Espinoza, J., Gantz, J.C., Himes, A., Rodstrom, A., Shuren, R., Stonex, R., Volk, T. and Zerpa, J. (2020) The Practice and Economics of Hybrid Poplar Biomass Production for Biofuels and Bioproducts in the Pacific Northwest. BioEnergy Research. https://doi.org/10.1007/s12155-020-10164-1

[26] Qiao, C., Sun, R., Xu, Z.W., Zhang, L., Liu, L.Y., Hao, L.Y. and Jiang, G.P. (2015) A Study of Shelterbelt Transpiration and Cropland Evapotranspiration in an Irrigated Area in the Middle Reaches of the Heihe River in Northwestern China. IEEE Geoscience and Remote Sensing Letters, 12, 369-373. https://doi.org/10.1109/LGRS.2014.2342219

[27] Chang, X.X., Zhao, W.Z., Zhang, Z.H. and Su, Y.Z. (2006) Sap Flow and Tree Conductance of Shelter-Belt in Arid Region of China. Agricultural and Forest Meteorology, 138, 132-141. https://doi.org/10.1016/j.agrformet.2006.04.003 
[28] Hinckley, T.M., Brooks, J.R., Cermak, J., Ceulemans, R., Kucera, J., Meinzer, F.C. and Roberts, D.A. (1994) Water Flux in a Hybrid Poplar Stand. Tree Physiology, 14, 1005-1018. https://doi.org/10.1093/treephys/14.7-8-9.1005

[29] Stimm, B., Stiegler, J., Genser, C., Wittkopf, S. and Mosandl, R. (2013) Paulownia-Hoffnungsträger aus Fernost? Eine schnellwachsende Baumart aus China in Bayern auf dem Prüfstand. Gastbaumarten im Klimawandel, 18-21.

[30] Villwock, D. (2019) Water Productivity of Poplar and Paulownia as Fast-Growing Trees in Central Asia. Master Thesis, University of Hohenheim, Stuttgart.

[31] Steppe, K., De Pauw, D.J.W., Doody, T.M. and Teskey, R.O. (2010) A Comparison of Sap Flux Density Using Thermal Dissipation, Heat Pulse Velocity and Heat Field Deformation Methods. Agricultural and Forest Meteorology, 150, 1046-1056. https://doi.org/10.1016/j.agrformet.2010.04.004

[32] Fuchs, S., Leuschner, C., Link, R., Coners, H. and Schuldt, B. (2017) Calibration and Comparison of Thermal Dissipation, Heat Ratio and Heat Field Deformation Sap Flow Probes for Diffuse-Porous Trees. Agricultural and Forest Meteorology, 244-245, 151-161. https://doi.org/10.1016/j.agrformet.2017.04.003

[33] Bush, S.E., Hultine, K.R., Sperry, S.J. and Ehleringer, J.R. (2010) Calibration of Thermal Dissipation Sap Flow Probes for Ring- and Diffuse-Porous Trees. Tree Physiology, 30, 1545-1554. https://doi.org/10.1093/treephys/tpq096

[34] Flo, V., Martinez-Vilaltaa, J. Steppe, K., Schuldt, B. and Poyatosa, R. (2019) A Synthesis of Bias and Uncertainty in Sap Flow Methods. Agricultural and Forest Meteorology, 271, 362-374. https://doi.org/10.1016/j.agrformet.2019.03.012

[35] Paris, P., Di Matteo, G., Tarchi, M., Tosi, L., Spaccino, L. and Lauteri, M. (2018) Precision Subsurface Drip Irrigation Increases Yield While Sustaining Water Use Efficiency in Mediterranean Poplar Bioenergy Plantations. Forest Ecology and Management, 409, 749-756. https://doi.org/10.1016/j.foreco.2017.12.013

[36] Delzon, S. and Loustau, D. (2005) Age-Related Decline in Stand Water Use: Sap Flow and Transpiration in a Pine Forest Chronosequence. Agricultural and Forest Meteorology, 129, 105-119. https://doi.org/10.1016/j.agrformet.2005.01.002 